\title{
Inactivation of Escherichia coli enhanced by anaerobic microbial iron reduction
}

\author{
Lavane $\mathrm{Kim}^{1}$ (D) ${\text { Tao } \mathrm{Yan}^{2} \cdot \text { Van Toan Pham }}^{1}$
}

Received: 13 May 2020 / Accepted: 9 October 2020 / Published online: 20 October 2020

(C) The Author(s) 2020

\begin{abstract}
Microbial iron reduction (MIR) is an important and ubiquitous natural process in the biogeochemical cycling of iron and carbon in anaerobic sedimentary and subsurface environments. The objectives of this study were (1) to determine if the MIR process can enhance the inactivation of Escherichia coli cells under anaerobic conditions and (2) to identify potential inactivation mechanisms. Laboratory microcosm experiments showed that the presence of MIR activity significantly enhanced $E$. coli inactivation, and the inactivation rate under the MIR condition was significantly larger than those under other anaerobic redox conditions. Under anoxic condition, higher $\mathrm{Fe}^{2+}$ concentrations exhibited a linear function to larger $E$. coli inactivation rates, indicating that the production of $\mathrm{Fe}^{2+}$ by MIR was one of the important roles in $E$. coli inactivation. When $E$. coli cells were amended as the sole electron source to the MIR process, increased $\mathrm{Fe}^{2+}$ production was observed, which corresponded to decreasing TOC concentration. Together, the results suggest that MIR enhanced $E$. coli inactivation through the production of $\mathrm{Fe}^{2+}$ as metabolic waste, and the inactivation benefited the MIR process as the inactivated cells were used as an electron source, which represents a potential new mechanism for bacterial inter-species competition. This knowledge could further improve our understanding of the fate of fecal bacteria in natural environments where the MIR process is prevalent, and may also be explored for enhanced removal of bacterial pathogens in engineering processes.
\end{abstract}

Keywords Inactivation $\cdot$ E. coli $\cdot$ Microbial iron reduction

\section{Introduction}

Microbial iron reduction (MIR) is an important and ubiquitous natural process in the biogeochemical cycling of iron and the oxidation of organic matter in anaerobic sedimentary and subsurface environments (Lovley 1991). Although nonenzymatic reduction of $\mathrm{Fe}(\mathrm{III})$ under anaerobic conditions can occur (Lovley et al. 1991), dissimilatory MIR by iron-

Responsible Editor: Robert Duran

Electronic supplementary material The online version of this article (https://doi.org/10.1007/s11356-020-11209-w) contains supplementary material, which is available to authorized users.

Lavane Kim

klavane@ctu.edu.vn

1 Department of Environmental Engineering, College of Environment and Natural Resources, Can Tho University, 3/2 Street, Xuan Khanh Ward, Ninh Kieu District, Can Tho City, Vietnam

2 Department of Civil and Environmental Engineering, University of Hawaii at Manoa, Honolulu, HI 96822, USA reducing bacteria (IRBs), which use $\mathrm{Fe}(\mathrm{III})$ as the terminal electron acceptor in respiration, is considered the most important mechanism in converting $\mathrm{Fe}(\mathrm{III})$ to $\mathrm{Fe}(\mathrm{II})_{\mathrm{aq}}$ (Lovley 1991; Weber et al. 2006). During the MIR process, IRBs can oxidize and mineralize a large variety of organic compounds and produce $\mathrm{CO}_{2}$ (Lovley et al. 1989; Lovley and Lonergan 1990; Lovley et al. 1992; Lu et al. 2008), which plays a major role in carbon cycling in anaerobic environments (Lovley 1991). Since Fe(III) substrates are usually insoluble, IRBs and mixed MIR communities including IRBs and archaea have evolved various strategies to transfer electrons, either through direct contact (Reguera et al. 2005) or via intermediate electron carriers (Lovley et al. 1996; Newman and Kolter 2000), to solid Fe(III) substrates. Since the initial isolation of Shewanella and Geobacter species (Lovley and Phillips 1988; Obuekwe et al. 1981), our knowledge about the phylogenetic diversity of IRBs has greatly expanded to include many species across the domain Bacteria (Lonergan et al. 1996; Lovley 2006), further reflecting the ubiquity of the MIR process in the environment. 
The metabolic capability of the MIR process has been extensively explored for biotechnology applications, including using $\mathrm{Fe}$ (III) to enhance the bioremediation of organic pollutants (Lovley 1991) and using the MIR communities to transfer electrons to external anodes for energy harvesting in microbial fuel cells (Bond et al. 2002). However, the possibility of using the MIR process in water purification, particularly in bacterial pathogen inactivation and removal, has not been investigated. Although anaerobic environments in general favor bacterial pathogen survival, the MIR process contains several features that may enhance pathogen inactivation. First of all, amorphous ferric oxides are known to be strong adsorbent for bacterial cells (Kapetas et al. 2012; Mills et al. 1994), which could concentrate bacterial cells on surfaces where MIR occurs. Second, the MIR process produces $\mathrm{Fe}^{2+}$ as a metabolic waste, which was recently shown to be a powerful bactericidal agent under anoxic conditions (Auffan et al. 2008; Kim et al. 2010; Lee et al. 2008). Thirdly, the metabolic diversity of IRBs and mixed MIR communities in degrading a large variety of organic substrates (Lovley et al. 1989; Lovley and Lonergan 1990; Lovley et al. 1992; Lu et al. 2008) indicates that cellular materials of inactivated fecal bacteria cells may be used as carbon and energy sources, which is supported by Shewanella's capability of consuming extracellular DNA (Gödeke et al. 2011).

Therefore, the objectives of this study were (1) to determine if MIR process can enhance the inactivation of the model organism Escherichia coli under anaerobic conditions and (2) to identify potential inactivation mechanisms. We hypothesis that survival of $E$. coli in sediment would be more strongly affected by MIR process than other processes under anoxic condition. Laboratory microcosms were established to compare the inactivation of $E$. coli cells in the presence/absence of MIR activity and between the MIR condition and other anaerobic redox conditions. E. coli inactivation in the presence of different $\mathrm{Fe}^{2+}$ concentrations was quantified to verify the bactericidal effect of $\mathrm{Fe}^{2+}$ under anoxic condition. The capability of the MIR process to use E. coli cells as the sole electron source for energy metabolism was also investigated.

\section{Materials and methods}

\section{Bacterial strains, cultivation, and enumeration}

E. coli ATCC 29522 was used as the model fecal bacterium in this study. A fresh single colony from overnight growth on a LB agar plate was used to inoculate LB broth, which was cultivated at $37^{\circ} \mathrm{C}$ with constant shaking at $200 \mathrm{rpm}$. Stationary-phase cells $\left(\mathrm{OD}_{600}>1.2\right)$ were collected by centrifugation at $10,000 \times g$ for $3 \mathrm{~min}$. The cell pellet was washed by resuspending in $0.1 \times \mathrm{PBS}$ buffer ( $\mathrm{pH}$ 7.2) and then pelleting by centrifugation for five times to remove residual broth nutrients. The cell pellet was subsequently resuspended in a sterile artificial freshwater medium (see below for composition) to prepare cell stock solution with a target $\mathrm{OD}_{600}$ of 0.8 , which contained approximately $10^{9}-10^{10} \mathrm{CFU} \mathrm{mL}{ }^{-1}$, and was used in subsequent inactivation experiments. E. coli in the stock solution and in samples collected from the experiments was enumerated by spread plating of appropriate 10 -fold sequential dilutions on the mTEC agar (USEPA 2002).

\section{Iron-coated sand preparation}

Quartz sand was coated by amorphous ferric oxyhydroxide $(\mathrm{FeOOH})$ following the procedure described by (Mills et al. 1994). Sand was heated at $550^{\circ} \mathrm{C}$ for $3 \mathrm{~h}$ and then rinsed several times with DI water to remove organic matters. Trace metal was washed by soaking the sand in concentrated $10 \mathrm{~mol} \mathrm{~L}^{-1} \mathrm{HCl}$ for $24 \mathrm{~h}$, then rinsing in $0.01 \mathrm{~mol} \mathrm{~L}^{-1} \mathrm{NaOH}$, and finally rinsed with DI water until the effluent $\mathrm{pH}$ reached $8.0 \pm 0.1$. Sand was dried at $110^{\circ} \mathrm{C}$ and then stored in a clean bottle for later use. The cleaned dry quartz sand was immersed in $400 \mathrm{~mL}$ of $\mathrm{FeCl}_{3}$ solution $\left(50 \mathrm{~g} \mathrm{~L}^{-1}\right.$ of $\left.\mathrm{FeCl}_{3} \cdot \mathrm{H}_{2} \mathrm{O}, \mathrm{pH} 1.9\right)$, and $30 \mathrm{~mL}$ of $\mathrm{NaOH}\left(0.5 \mathrm{~mol} \mathrm{~L}^{-1}\right)$ was added instantaneously followed by gradual addition of $1 \mathrm{~mL} \mathrm{NaOH}\left(0.5 \mathrm{~mol} \mathrm{~L}^{-1}\right)$ until $\mathrm{pH}$ reaches 4.5-5.0. The mixture was then shaken for $36 \mathrm{~h}$ to allow further coating of $\mathrm{FeOOH}$ onto sand surfaces. Iron-coated sand was then rinsed with DI water, air dried, and saved in a clean bottle for later use.

\section{Microbial inoculum preparation}

Anaerobic microbial inocula were first enriched using $\mathrm{FeOOH}, \mathrm{SO}_{4}{ }^{2-}$, and $\mathrm{NO}_{3}{ }^{-}$as the terminal electron acceptor for iron-reducing bacteria (IRBs), sulfate-reducing bacteria (SRBs), and denitrifiers, respectively. Artificial freshwater medium used in the enrichment contained $2.5 \mathrm{~g} \mathrm{~L}^{-1}$ $\mathrm{NaHCO}_{3}, 0.1 \mathrm{~g} \mathrm{~L}^{-1} \mathrm{NaCl}, 0.1 \mathrm{~g} \mathrm{~L}^{-1} \mathrm{KCl}, 0.1 \mathrm{~g} \mathrm{~L}^{-1}$ $\mathrm{MgCl}_{2} .6 \mathrm{H}_{2} \mathrm{O}, 0.1 \mathrm{~g} \mathrm{~L}^{-1} \mathrm{CaCl}_{2} .2 \mathrm{H}_{2} \mathrm{O}, 1.5 \mathrm{~g} \mathrm{~L}^{-1} \mathrm{NH}_{4} \mathrm{Cl}$, $0.6 \mathrm{~g} \mathrm{~L}^{-1} \mathrm{NaH}_{2} \mathrm{PO}_{4}, 0.005 \mathrm{~g} \mathrm{~L}^{-1} \mathrm{MnCl}_{2} .4 \mathrm{H}_{2} \mathrm{O}, 0.001 \mathrm{~g} \mathrm{~L}^{-1}$ $\mathrm{NaMoO}_{4}$, and $0.05 \mathrm{~g} \mathrm{~L}^{-1}$ yeast extract (Lovley and Phillips 1988). The enrichments were established in $160-\mathrm{mL}$ serum bottles, containing $100 \mathrm{~mL}$ of artificial freshwater medium and $10 \mathrm{mmol} \mathrm{L}^{-1}$ of sodium acetate as the electron donor. The microcosm for IRB enrichment contained $20 \mathrm{~g}$ of $\mathrm{FeOOH}$-coated quartz sand, the microcosm for SRB enrichment contained $10 \mathrm{mmol} \mathrm{L}^{-1}$ of $\mathrm{MgSO}_{4}$, and the microcosm for denitrifiers contained $10 \mathrm{mmol} \mathrm{L}^{-1} \mathrm{MgNO}_{3}$. The microcosms were inoculated with $1 \mathrm{~g}$ of anaerobic sediment sample collected from a pond near the Waipahu Stream $\left(21^{\circ} 23^{\prime} 05.9^{\prime \prime}\right.$ $\mathrm{N}, 158^{\circ} 00^{\prime} 46.4^{\prime \prime} \mathrm{W}$ ) where iron-rich Haplustoll soil is present. The serum bottles were capped with rubber stopper and sealed with aluminum crimp caps. Air in the head space of serum bottles was removed by vacuum and followed by 15 min $\mathrm{N}_{2}$ bubbling for three times. The microcosm was 
incubated at room temperature in dark, and the enrichment of IRBs, SRBs, and denitrifiers was verified by $\mathrm{Fe}^{2+}$ accumulation, $\mathrm{SO}_{4}{ }^{2-}$ concentration reduction, and $\mathrm{NO}_{3}{ }^{-}$concentration reduction, respectively (data not shown). To pool the three inocula into one anaerobic inoculum, the microcosms were thoroughly shaken by hand for $3 \mathrm{~min}$, and $10 \mathrm{~mL}$ of each suspension was withdrawn with a syringe and injected into an anoxic serum bottle. The microbial community of the pooled anaerobic inoculum was determined by Illumina sequencing of $16 \mathrm{~S}$ rRNA gene following the procedure described by Zhang et al. (2015). The microbial community contained common IRBs, SRBs, and denitrifiers (Table S1).

\section{Microcosm setup with different redox conditions}

Anaerobic microcosms to determine the decay kinetics of $E$. coli cells under different redox conditions were established in the same way as the inoculum enrichment described above. Four sets of microcosms, each containing three independent microcosms as biological replicates, were established. Two sets of identical microcosms contained $\mathrm{FeOOH}$-coated quartz sand, with one set receiving the anaerobic inoculum (termed active MIR microcosms) and the other set receiving no inoculum and hence remaining sterile (control microcosms). The active MIR microcosms and the control microcosms were used to compare the effect of active MIR activity on E. coli inactivation. The microcosms receiving sulfate were to establish microbial sulfate reduction (MSR) condition, while the microcosms receiving nitrate were to establish microbial nitrate reduction condition (MNR). The MSR and MNR microcosms were used to compare with the $E$. coli inactivation in the MIR microcosms. The pooled anaerobic inoculum $(1 \mathrm{~mL})$ was injected into the MIR, MSR, and MNR microcosms using a syringe. Equal amounts of $E$. coli cells (ca. $3 \times 10^{9} \mathrm{CFU}$ ) were also injected into all microcosms using freshly prepared E. coli stock solutions. The microcosms were then incubated at room temperature in dark without shaking. Samples were collected daily by first vigorously shaking serum bottles for $2 \mathrm{~min}$ followed by immediately withdrawing $1 \mathrm{~mL}$ of the mixtures using a syringe.

\section{Inactivation of $E$. coli by $\mathrm{Fe}^{2+}$}

The impact of different $\mathrm{Fe}^{2+}$ concentrations on the inactivation of $E$. coli was investigated in $50 \mathrm{~mL}$ serum bottles under anoxic conditions. Each bottle contained $30 \mathrm{~mL}$ of $0.1 \times$ PBS buffer that was deoxygenated by flushing $\mathrm{N}_{2}$ into the headspace for 15 min before sealed off with a rubber stopper and aluminum seal. E. coli cells from the stock solution were injected into the bottles to reach an initial cell concentration of approximately $10^{7} \mathrm{CFU} \mathrm{mL} \mathrm{m}^{-1}$. Different final concentrations of $\mathrm{Fe}^{2+}\left(0,0.05,0.1,0.2\right.$, and $\left.0.5 \mathrm{mmol} \mathrm{L}^{-1}\right)$ were added into the bottles to make the experimental treatments. Each treatment used three bottles as biological replicates. The bottles were incubated under the anoxic condition at room temperature $\left(22 \pm 0.5^{\circ} \mathrm{C}\right)$ on a shaker at $40 \mathrm{rpm}$. Samples were taken from each bottle $(1 \mathrm{~mL})$ after fully mixing at different incubation times $(0,1,12,36$, and $60 \mathrm{~h})$. The samples were subjected to 10 -fold serial dilution in sterile $0.1 \times$ PBS buffer, and the culturable E. coli cells were enumerated as described above.

\section{Carbon source experiment}

Three sets of MIR microcosms, each in triplicate, were also established to test if $E$. coli cells could be used as the sole carbon source for MIR. The basic microcosms setup was the same as described above, except for the carbon source. The microcosms either received sodium acetate (final concentration $\left.0.2 \mathrm{mmol} \mathrm{L}^{-1}\right)$, E. coli cells (ca. $10^{10} \mathrm{CFU}$ ), or no carbon source (control). The carbon source equivalency of the spiked E. coli cells was determined by first autoclaving the samples at $121{ }^{\circ} \mathrm{C}$ for $20 \mathrm{~min}$ to lyse the cells and then analyzing the cell lysates by TOC analysis (described below), which gave an average TOC of $232.6 \mathrm{mg} \mathrm{C} \mathrm{L}^{-1}$. The acetate concentration used $\left(0.2 \mathrm{mmol} \mathrm{L}^{-1}\right)$ gives a theoretical TOC of $4.8 \mathrm{mg} \mathrm{C} \mathrm{L}^{-1}$, and the measured TOC concentration was $2.7 \pm 0.3 \mathrm{mg} \mathrm{C} \mathrm{L}^{-1}$. The microcosms were inoculated by injecting $1 \mathrm{~mL}$ of the anaerobic inoculum using a syringe. All microcosms were incubated at room temperature, in dark, and without shaking. The microcosms were sampled daily using the same procedure described above, and the samples were analyzed for $\mathrm{Fe}^{2+}$ and TOC.

\section{Chemical analysis}

$\mathrm{Fe}^{2+}$ was measured using the colorimetric ferrozine assay (Stookey 1970) following the procedure described by Lovley and Phillips (1986). Briefly, liquid samples $(0.1 \mathrm{~mL})$ were transferred into $5 \mathrm{~mL}$ of ferrozine $\left(1 \mathrm{~g} \mathrm{~L}^{-1}\right)$ in $50 \mathrm{mmol}$ $\mathrm{L}^{-1}$ HEPES (N-2-hydroxyethylpiperazine-N' -2 ethanesulfonic acid) buffer $(\mathrm{pH} 7)$. The mixtures were vortexed for $15 \mathrm{~s}$ and then filtered through a Nuclepore filter $(0.2 \mu \mathrm{m})$. Filtrates were measured for light absorbance at wavelength $562 \mathrm{~nm}$ using a spectrometer (Hach DR/4000 $\mathrm{U}$ ), and $\mathrm{Fe}^{2+}$ concentration was calculated based on standard curves established by using ferrous ethylene-diammonium sulfate as standard solutions. Anions $\left(\mathrm{SO}_{4}{ }^{2-}\right.$ and $\left.\mathrm{NO}_{3}{ }^{-}\right)$were quantified by using a Dionex ICS-1100 Ion Chromatograph equipped with a $4 \mathrm{~mm}$ AS14A analytical column. $25 \mu \mathrm{L}$ of samples was injected into the analytical system by an AS-DV auto-sampler utilizing Dionex filter cap vials that automatically filter the samples before loading into injection loop. TOC concentration in the samples was determined by using a TOC analyzer (Shimadzu). 


\section{Data analysis}

The $\mathrm{Fe}^{2+}$ concentration difference between the sterile control microcosms and active MIR microcosms was tested using $t$ test for individual sampling dates. The $\mathrm{Fe}^{2+}$ production rate during the three sequential periods following repetitive $E$. coli cell spikes were determined by linear regression of $\mathrm{Fe}^{2+}$ concentration data versus time. $E$. coli cell inactivation was modeled using the 1st-order model $\left(\operatorname{Ln}\left(\frac{C_{t}}{C_{0}}\right)=-k_{\mathrm{d}} t\right)$, where $\mathrm{C}_{\mathrm{t}}$ and $C_{0}$ are the concentrations of $E$. coli cells in the microcosms at time $t$ and time zero, respectively. $k_{\mathrm{d}}$ is the decay coefficient of the 1st-order decay model and was identified through linear regression of natural log-transformed concentration data. A comparison of $E$. coli inactivation rates was performed using ANCOVA with Tukey's post hoc test. ANOVA was used to test if there was difference in $E$. coli concentration in the $\mathrm{Fe}^{2+}$ inactivation experiment, and to test if $\mathrm{Fe}^{2+}$ and TOC concentrations were different among the different carbon source treatments. Statistical tests were conducted either in the Microsoft Excel with a statistiXL plug-in or using Sigma 10.0, and the default significant level is 0.05 , unless stated otherwise.

\section{Results}

\section{E. coli inactivation in the presence of MIR}

The impact of MIR on the inactivation of $E$. coli cells was investigated by comparing the decay patterns of $E$. coli cells in the active MIR microcosms, which received the anaerobic inoculum, to those in the control microcosms, which did not receive the anaerobic inoculum. During the incubation, $\mathrm{Fe}^{2+}$ concentration in the active MIR microcosms continued to increase over time, and became significantly higher than that in the control microcosms after day 1 ( $t$ test, $P<0.05$ ), indicating successful development of MIR activity (Fig. 1a). The $\mathrm{Fe}^{2+}$ production rates were calculated to be $0.65,1.20$, and $5.78 \mu \mathrm{mol} \mathrm{L}^{-1}$ day $^{-1}$ for the three periods following the three repetitive spikes of $E$. coli cells on days 0,13 , and 25 , respectively. The $\mathrm{Fe}^{2+}$ production rate in the second period was higher than that in the first period (although not statistically significant, $P=0.829$ ); the $\mathrm{Fe}^{2+}$ production rate was significantly higher in the third period than in the first two periods (ANCOVA, $P<0.001$ ), indicating a continuous and significant increase in MIR activity over time.

Significantly faster inactivation of $E$. coli cells was observed in the active MIR microcosms than in the control microcosms following all three repetitive spikes of $E$. coli cells (Fig. 1b). The control microcosms exhibited negligible E. coli inactivation during the experimental course. In the active MIR microcosms, E. coli exhibited first-order inactivation rates of

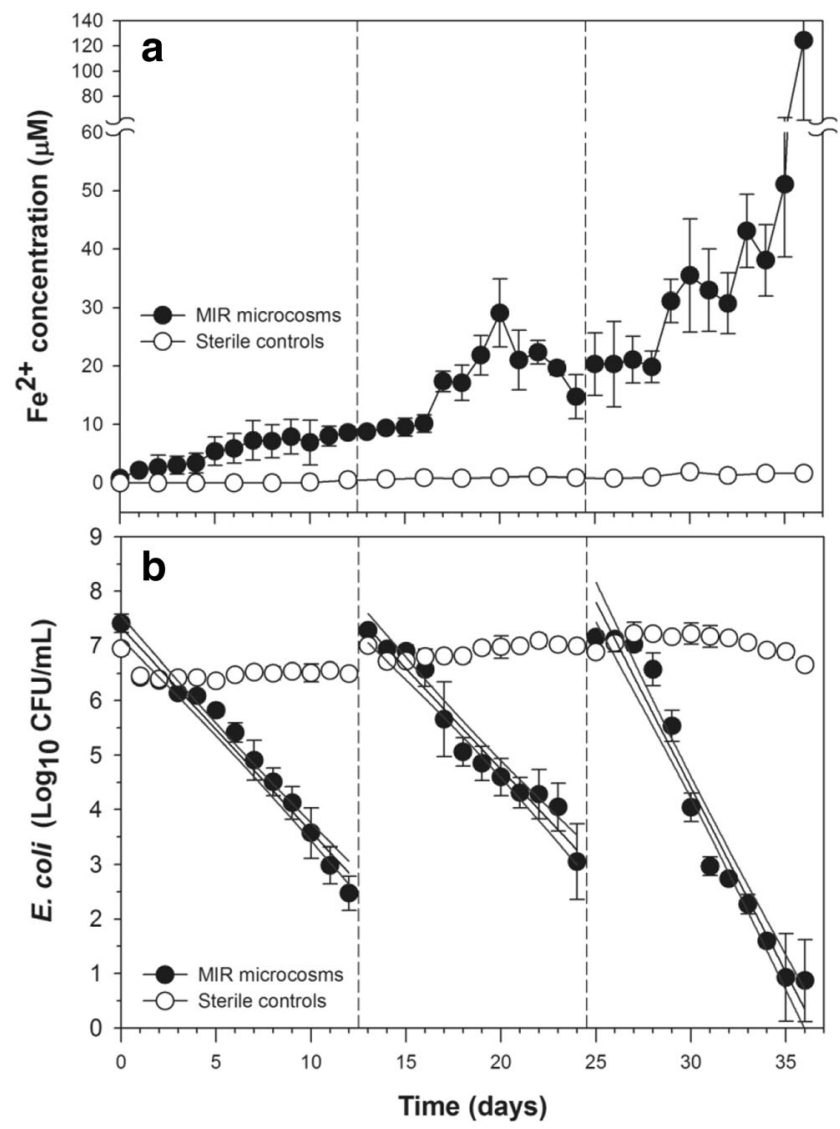

Fig. 1 Production of $\mathrm{Fe}^{2+}$ (a) and inactivation of E. coli cells (b) in the active microbial iron reduction and control microcosms. Repetitive spike of $E$. coli cells (c.a. $10^{7} \mathrm{CFU} \mathrm{mL} \mathrm{mL}^{-1}$ ) occurred on days 0,12 , and 24 , as indicated by the dashed lines. Error bars indicate the standard deviation of the mean of triplicate microcosms

$0.86,0.85$, and $1.56 \mathrm{day}^{-1}$ in the three periods following the three repetitive spikes, respectively (Table 1). A significant difference was detected among the three decay rates, and Tukey's post hoc tests showed that there was no significant difference in the inactivation rates during the first two periods ( 0.86 and $\left.0.85 \mathrm{day}^{-1}\right)$; inactivation rate after the third spike $\left(1.56 \mathrm{day}^{-1}\right)$ was significantly higher than those observed after the first two periods (ANCOVA, $P<0.001$ ). The increasingly higher $E$. coli inactivation rates corresponded well to the increasingly higher MIR activity over the experimental course.

\section{Comparison with other anaerobic redox conditions}

To further test the impact of MIR activity on E. coli inactivation, the MIR microcosms were also compared with the MSR and MNR microcosms, which had the same microcosm setup as the MIR microcosms, receiving the same anaerobic inoculum, but were provided with $\mathrm{SO}_{4}{ }^{2-}$ or $\mathrm{NO}_{3}{ }^{-}$, respectively, to establish different anaerobic redox conditions. Microbial sulfate reduction and nitrate reduction were developed in the MSR and MNR microcosms, respectively, as indicated by the gradual decrease of $\mathrm{SO}_{4}{ }^{2-}$ and $\mathrm{NO}_{3}{ }^{-}$concentration over 
Table 1 Average inactivation rates of $E$. coli cells in microcosms under different redox conditions $\left(k_{\mathrm{MIR}}, k_{\mathrm{MNR}}\right.$, and $\left.k_{\mathrm{MSR}}\right)$, goodness-of-fit of the linear regression $\left(r^{2}\right)$, and rate comparisons*

\begin{tabular}{lllllllll}
\hline Spike & $k_{\mathrm{MIR}}$ & $r^{2}$ & $k_{\mathrm{MNR}}$ & $r^{2}$ & $k_{\mathrm{MSR}}$ & $r^{2}$ & $k_{\mathrm{MIR}}>k_{\mathrm{MNR}}$ & $k_{\mathrm{MIR}}>k_{\mathrm{MSR}}$ \\
\hline 1 & $0.86 \pm 0.03$ & 0.95 & $0.74 \pm 0.04$ & 0.88 & $0.24 \pm 0.02$ & 0.78 & $P=0.04$ & $P<0.001$ \\
2 & $0.85 \pm 0.05$ & 0.91 & $0.45 \pm 0.05$ & 0.73 & $0.27 \pm 0.03$ & 0.65 & $P<0.001$ & $P<0.001$ \\
3 & $1.56 \pm 0.06$ & 0.95 & $0.87 \pm 0.06$ & 0.84 & $0.60 \pm 0.04$ & 0.89 & $P<0.001$ & $P<0.001$ \\
\hline
\end{tabular}

*ANCOVA with Tukey's post hoc test time (Figure S1). The different microcosms exhibited different E. coli inactivation patterns, with the MIR microcosms showing the fastest inactivation after all three repetitive spikes (Fig. 2). Fitting of the E. coli inactivation data to the first-order model gave inactivation rates of $0.45-0.87$ day $^{-1}$ and 0.24 0.60 day $^{-1}$ for the MNR and MSR microcosms, respectively, which were significantly smaller than the those in the MIR microcosms after all three repetitive spikes of $E$. coli cells (ANCOVA, $P \leq 0.04)$ (Table 1$)$.

\section{Inactivation of $E$. coli cells by ferrous ion}

The bactericidal effect of $\mathrm{Fe}^{2+}$ produced from the MIR activity was investigated by determining $E$. coli inactivation rates in the presence of different $\mathrm{Fe}^{2+}$ concentrations under anoxic condition (Fig. 3a). E. coli inactivation was negligible in the absence of $\mathrm{Fe}^{2+}$ over the entire $60 \mathrm{~h}$ of incubation, while significantly lower $E$. coli concentrations were observed in the presence of $\mathrm{Fe}^{2+}$ within the first hour of incubation (ANOVA, $P<0.01)$. Since majority of $E$. coli inactivation occurred within the first hour and then tailed off almost completely, the initial $E$. coli inactivation rates were calculated using the inactivation data within the first hour (Fig. 3b). Higher $\mathrm{Fe}^{2+}$ concentrations corresponded to larger E. coli inactivation

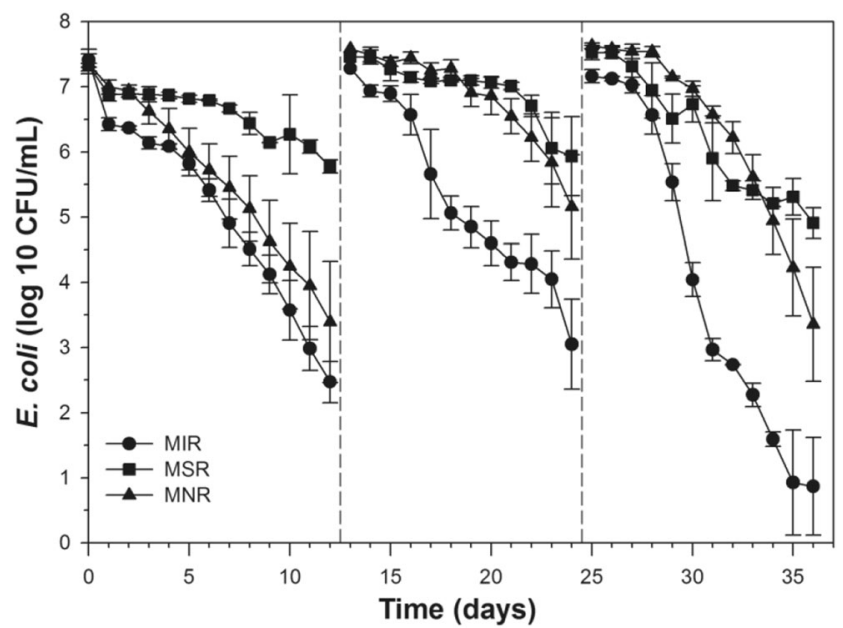

Fig. 2 Inactivation of $E$. coli cells under different redox conditions (microbial iron reduction, microbial sulfate reduction, and microbial nitrate reduction). Repetitive spike of E. coli cells (c.a. $10^{7} \mathrm{CFU} \mathrm{mL}{ }^{-1}$ ) occurred on days 0,12 , and 24 , as indicated by the dashed lines. Error bars indicate the standard deviation of the mean of triplicate microcosms rates; the microcosms receiving $0,0.05,0.1,0.2$, and $0.5 \mathrm{mmol}$ $\mathrm{L}^{-1} \mathrm{Fe}^{2+}$ exhibited initial decay rates of $0.001,0.44,0.81,2.5$, and $6.1 \mathrm{~h}^{-1}$, respectively. The observed $E$. coli inactivation rates showed a linear relationship to $\mathrm{Fe}^{2+}$ concentrations, as indicated by the excellent goodness-of-fit $\left(r^{2}=0.99\right)$.

\section{E. coli cells as sole electron source}

The capability of MIR to use $E$. coli cells as the sole electron source was determined by comparing $\mathrm{Fe}^{2+}$ production in MIR microcosms that received $E$. coli cells $\left(2.8 \times 10^{10} \mathrm{CFU} \mathrm{mL}^{-1}\right)$
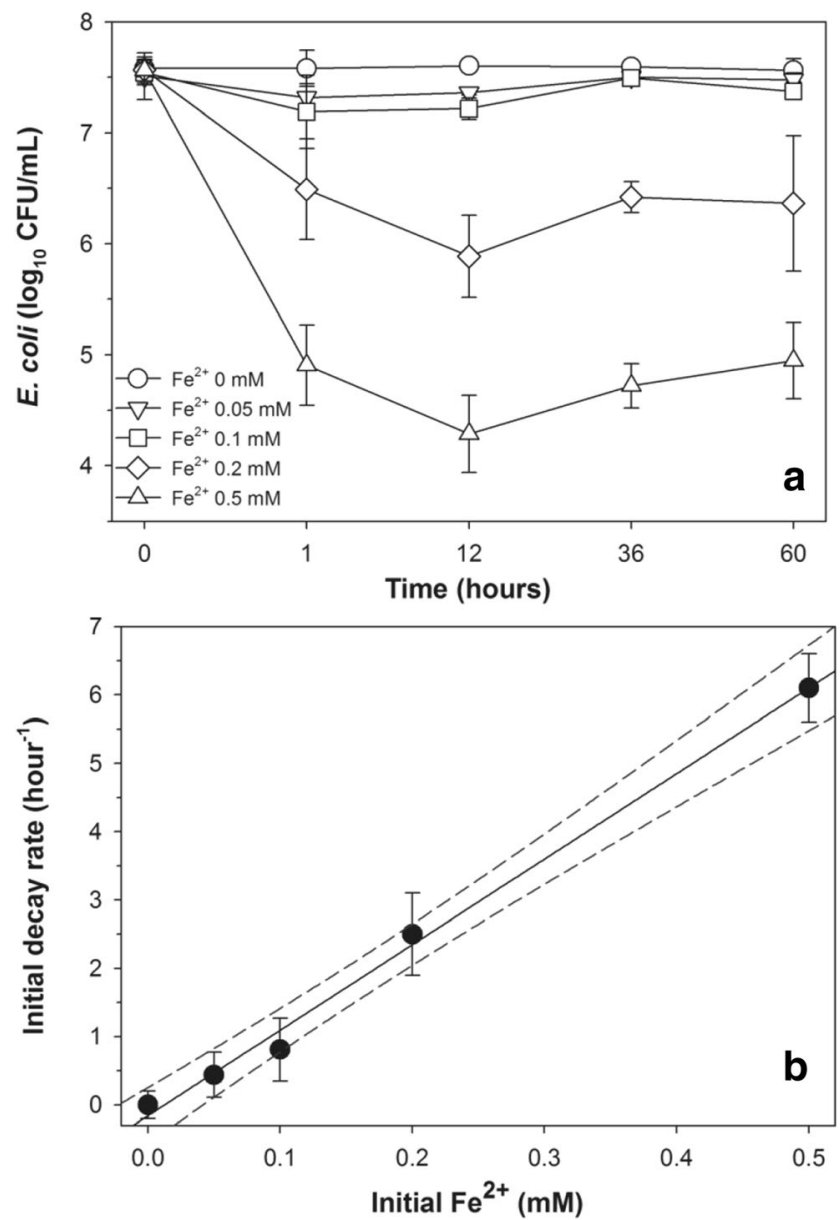

Fig. 3 Inactivation of $E$. coli under different $\mathrm{Fe}^{2+}$ concentration over different exposure times (a), and linear regression between the firsthour inactivation rate and $\mathrm{Fe}^{2+}$ concentration (b). Error bars indicate the standard deviation of the mean of triplicate microcosms. The dashed lines in compartment B represent $95 \%$ confidence bands 
to two sets of control microcosms that received either $0.2 \mathrm{mmol} \mathrm{L}^{-1}$ either acetate (positive control) or no carbon source (negative control) (Fig. 4a). On day 0, there was no significant difference in $\mathrm{Fe}^{2+}$ concentration among all microcosms (ANOVA, $P=0.99$ ). Starting from day 1 to day 8 , the positive control microcosms showed a $\mathrm{Fe}^{2+}$ concentration range of 50.6 to $75.7 \mu \mathrm{mol} \mathrm{L}^{-1}$, which were significantly higher than those in the negative controls (ANOVA, $P<$ 0.001 ), indicating the development of active MIR activity in the microcosms. The negative control microcosms showed very low $\mathrm{Fe}^{2+}$ concentrations and negligible fluctuation over the eight-day experimental course (concentration range: 2.6$15.4 \mu \mathrm{mol} \mathrm{L}^{-1}$ ).

Starting from day 1, the microcosms that received $E$. coli cells as the sole carbon source showed significantly higher concentrations of $\mathrm{Fe}^{2+}$ than both sets of control microcosms (ANOVA, $P<$ 0.001). The $\mathrm{Fe}^{2+}$ concentration continued to increase over time, reached $995.2 \pm 26.1 \mu \mathrm{mol} \mathrm{L}{ }^{-1}$ on day 6 , and then gradually tailed off. Correspondingly, initial TOC concentrations in the MIR microcosms that received $E$. coli cells was also significantly higher than the two sets of control microcosms, and its decreasing pattern over time, which tailed off after day 6 , coincided with the $\mathrm{Fe}^{2+}$ concentration increase pattern.
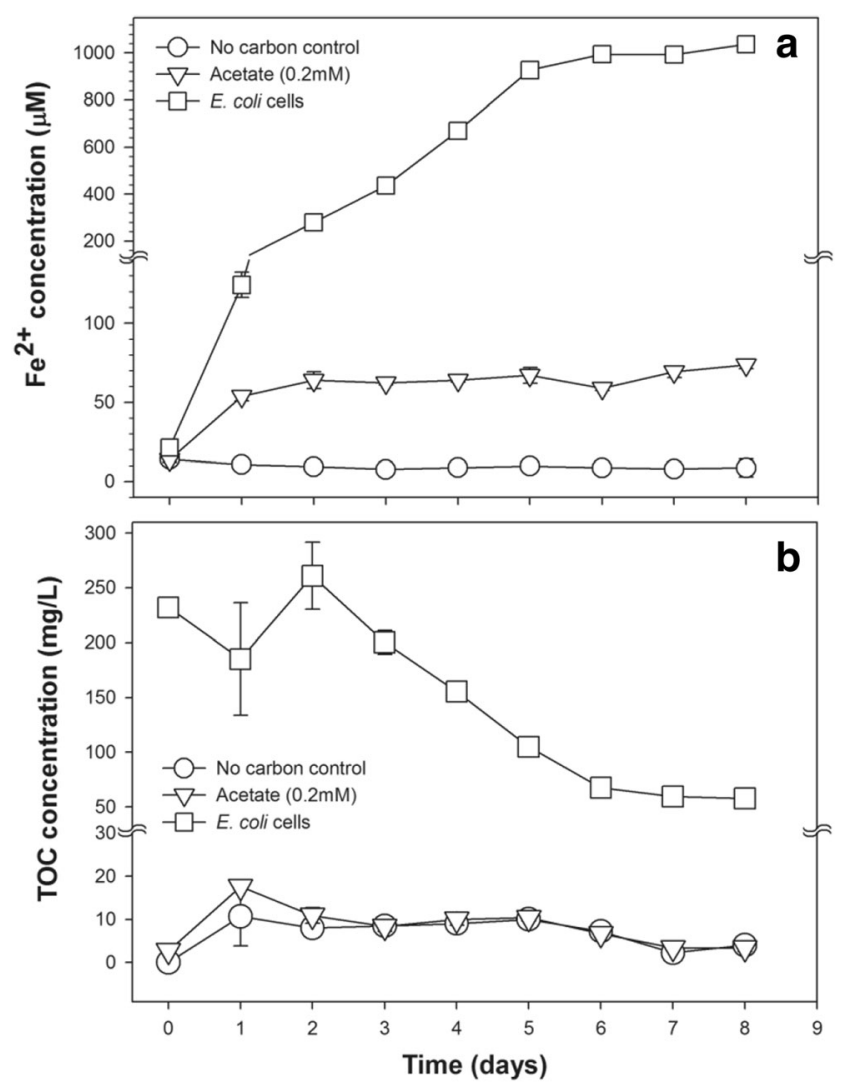

Fig. $4 \mathrm{Fe}^{2+}$ concentrations in microbial iron reduction microcosms that received no carbon, acetate, or E. coli cells as the sole electron source (a), and their corresponding TOC concentration change over time (b). Error bars indicate the standard deviation of the mean of triplicate microcosms

\section{Discussions}

The impact of MIR activity on the inactivation of $E$. coli cells was clearly demonstrated by the significantly faster decay in the active MIR microcosms than in the sterile control microcosms, which was repetitively observed over the three sequential spikes of E. coli cells (Fig. $1 \mathrm{~b}$ and Table 1). Since the only difference between the active MIR and the control microcosms was the anaerobic inoculum, the observed difference in decay patterns should be primarily attributed to the presence of the anaerobic inoculum and resulting MIR activity in the active MIR microcosms. The limited E. coli concentration reduction over time in the control microcosms indicates that abiotic factors, such as cell recovery from the iron-coated surface (Kapetas et al. 2012; Mills et al. 1994) and abiotic inactivation by iron oxide surface (Asadishad et al. 2013), made a limited contribution to the reduction of culturable $E$. coli cell number under the experimental conditions. Endogenous decay of E. coli cells under sterile anaerobic conditions is usually very slow (Feng et al. 2010), which is in line with the slow E. coli inactivation observed in the sterile control microcosms.

The correspondence between higher MIR activity and faster inactivation rate (Fig. 1) and the faster inactivation under the MIR condition than under the MNR and MSR redox conditions (Fig. 2) provided further support to the association between MIR activity and enhanced $E$. coli inactivation. In the active MIR microcosm, increasingly higher $\mathrm{Fe}^{2+}$ production rates over time indicate continuous growth of iron-reducing bacteria and higher MIR activity in the third period than in the first two (Fig. 1b). This is in agreement with the slow growth of IRBs; for example, the growth rate of Geobacter metallireducens was reported to be below $0.003 \mathrm{~h}^{-1}$ (Marozava et al. 2014).

Comparing E. coli inactivation in the MIR microcosms to that in the MNR and MSR microcosms provided further support to the superiority of MIR on E. coli inactivation. The MIR, MNR, and MSR microcosms started with the same anaerobic inoculum, and the development of respective anaerobic activities followed the normal expectation of typical growth rates of the individual anaerobic organisms (i.e., MNR > MSR > MIR). Although during the first spike, there was no significant difference in inactivation rates between the MIR and MNR microcosms, significantly faster inactivation of $E$. coli cells was observed in the MIR microcosms than the other microcosms during both the second and third spikes. The increasingly larger difference in decay rates between the MIR microcosms and other microcosms as time progressed corresponded well to its slower growth rate in comparison to MNR and MSR, suggesting that even faster inactivation could be achievable with higher MIR activity.

The observation of significantly faster $E$. coli inactivation in the presence of MIR activities highlights the importance of 
biotic stresses to the inactivation of fecal bacteria. Several recent studies have shown that $E$. coli often exhibit significantly faster decay rates in the presence of indigenous microbiota in soil (Bogosian et al. 1996; Medema et al. 1997), freshwater (Bogosian et al. 1996; Medema et al. 1997), seawater (Carlucci et al. 1961), and beach sand (Feng et al. 2010). Different types of biotic stresses, including protozoa predation (Enzinger and Cooper 1976; Gonzalez et al. 1992), phage infection (Ashelford et al. 2003; Rozen and Belkin 2001), and bacterial competition (Feng et al. 2010; Hibbing et al. 2010; Jannasch 1968; Mitchell and Nevo 1965; Mitchell et al. 1967), have been shown to play significant roles in $E$. coli inactivation in the environment. The significant difference in $E$. coli inactivation between the different redox conditions indicates that bacterial competition from the MIR community played a significant role in the observed E. coli cell inactivation.

Bacterial interspecies competition can involve many different mechanisms, such as nutrient competition and antibiotic production (Hibbing et al. 2010). Although bacterial metabolic wastes are generally considered to be adverse to the waste producer themselves, their impact to other bacterial populations, particular those allochthonous to the prevailing microbial community, has not been explicitly studied. Previous works have shown that $\mathrm{Fe}^{2+}$ can inactivate $E$. coli cells under anoxic conditions (Auffan et al. 2008; Kim et al. 2010; Lee et al. 2008), and results in this study suggest that the $\mathrm{Fe}^{2+}$ produced as a metabolic waste of MIR can rapidly inactivate E. coli cells (Fig. 3) and hence may function as a mechanism in bacterial interspecies competition. Since many soil bacteria can produce secondary metabolites (antibiotics) to participate in interspecies competition (D'Costa et al. 2006), it is not totally surprising bacterial metabolic wastes may also fulfill similar ecological functions.

Regarding the chemical mechanism underlying the inactivation, previous authors suggested that $\mathrm{Fe}^{2+}$ could have reacted with intracellular $\mathrm{H}_{2} \mathrm{O}_{2}$ to produce reactive oxygen species (such as hydroxyl radical) via the Fenton's reaction (Kim et al. 2010; Lee et al. 2008), which are strong oxidants with bactericidal effects (Imlay 2013). Aerobically grown E. coli cells typically generate $14 \mu \mathrm{mol} \mathrm{L} \mathrm{L}^{-1}$ of $\mathrm{H}_{2} \mathrm{O}_{2}$ per second (Seaver and Imlay 2001) and maintain a steady-state 0.1$0.2 \mu \mathrm{mol} \mathrm{L}^{-1}$ of $\mathrm{H}_{2} \mathrm{O}_{2}$ due to various scavenging mechanisms (Gonzalez-Flecha and Demple 1995). Although the intracellular $\mathrm{H}_{2} \mathrm{O}_{2}$ produced under aerobic condition could have persisted and been carried over into the anoxic condition used in this study, the linear dependency of $E$. coli inactivation on $\mathrm{Fe}^{2+}$ concentration observed here and in previous studies (Auffan et al. 2008; Kim et al. 2010; Lee et al. 2008) suggest $\mathrm{Fe}^{2+}$, rather than intracellular $\mathrm{H}_{2} \mathrm{O}_{2}$, was the limiting factor, hence partially dissuading the contribution from Fenton's reaction. Further researches needed to fully elucidate the inactivation mechanism(s).
The inactivated $E$. coli cells were used as the sole electron source in the MIR process, as indicated by the increase in $\mathrm{Fe}^{2+}$ concentration and concurrent reduction of TOC in the microcosms (Fig. 4). Individual IRBs are capable of using a wide variety of organic substrates as an electron source for respiratory energy generation, including short-chain fatty acids (Fredrickson et al. 2008; Lovley et al. 1992), low molecular weight petroleum organics (Jahn et al. 2005; Kazumi et al. 1995; Lovley et al. 1989; Lovley and Lonergan 1990; Lu et al. 2008), aromatic compounds (Lovley et al. 1989; Lovley and Lonergan 1990; Lovley et al. 1992; Lu et al. 2008), and even extracellular DNA (Gödeke et al. 2011). With the assistance of other members in the complex MIR community, some of which may be equipped to degrade other bacterial cellular components (Mitchell and Nevo 1965), the MIR community could efficiently degrade the inactivated $E$. coli cells and couple that to dissimilatory iron reduction. This coupling potentially provides an ecological impetus for the MIR community to inactivate exogenous $E$. coli cells, providing a positive feedback loop as more $\mathrm{Fe}^{2+}$ inactivates more $E$. coli cells, which leads to higher MIR activity and higher $\mathrm{Fe}^{2+}$.

Since MIR is an important biogeochemical process in sedimentary and subsurface environments and is known to enhance the biodegradation of a large variety of organic pollutants, MIR is expected to influence water quality in such environments (Lovley 2006). Results from this study, for the first time, demonstrated that the MIR activity can also significantly enhance the inactivation of $E$. coli, and by inference other fecal bacteria. The production of $\mathrm{Fe}^{2+}$ as the metabolic waste of MIR was identified as a mechanism in E. coli inactivation under the anaerobic condition. Since the inactivated E. coli cells were shown to be used by the MIR community as an electron source to drive $\mathrm{Fe}(\mathrm{III})$ reduction, this represents a new mechanism for bacterial interspecies competition. This knowledge could further improve our understanding of the fate of fecal bacteria in natural sedimentary and subsurface environments where the MIR process is prevalent, and may also be explored for the enhancement of pathogen removal in many engineering processes, such as stormwater bioretention facilities, aquifer artificial recharge, and low-cost soil-based water reclamation.

Acknowledgments The authors would like to acknowledge Mr. Joseph Lichwa for the help with chemical analyses and Dr. Qian Zhang for the assistance with microbial community analysis of the anaerobic inoculum by Illumina sequencing.

Author Contributions Lavane Kim carried out all experiments, analyzed and interpreted the data, and drafted and revised the manuscript; Dr. Tao Yan conceived the idea, supervised the experiments, analyzed and interpreted the data, and proofread the final manuscript; Dr. Toan Pham Van revised and proofread the final version to be published. 
Funding This study was funded in part by the Can Tho University Improvement Project VN14-P6, supported by a Japanese ODA loan.

Data availability Not applicable.

\section{Compliance with ethical standards}

Ethical approval This article does not contain any study with human and animals performed by any of the author

Consent to participate Not applicable.

Consent to publish Not applicable.

Competing interests The authors declare that they have no conflict of interest.

Open Access This article is licensed under a Creative Commons Attribution 4.0 International License, which permits use, sharing, adaptation, distribution and reproduction in any medium or format, as long as you give appropriate credit to the original author(s) and the source, provide a link to the Creative Commons licence, and indicate if changes were made. The images or other third party material in this article are included in the article's Creative Commons licence, unless indicated otherwise in a credit line to the material. If material is not included in the article's Creative Commons licence and your intended use is not permitted by statutory regulation or exceeds the permitted use, you will need to obtain permission directly from the copyright holder. To view a copy of this licence, visit http://creativecommons.org/licenses/by/4.0/.

\section{References}

Asadishad B, Ghoshal S, Tufenkji N (2013) Short-term inactivation rates of selected gram-positive and gram-negative bacteria attached to metal oxide mineral surfaces: role of solution and surface chemistry. Environ Sci Technol 47:5729-5737. https://doi.org/10.1021/ es4003923

Ashelford KE, Day MJ, Fry JC (2003) Elevated abundance of bacteriophage infecting bacteria in soil. Appl Environ Microbiol 69:285289

Auffan M et al (2008) Relation between the redox state of iron-based nanoparticles and their cytotoxicity toward Escherichia coli. Environ Sci Technol 42:6730-6735. https://doi.org/10.1021/ Es800086f

Bogosian G, Sammons LE, Morris PJ, O’Neil JP, Heitkamp MA, Weber DB (1996) Death of the Escherichia coli K-12 strain W3110 in soil and water. Appl Environ Microbiol 62:4114-4120

Bond DR, Holmes DE, Tender LM, Lovley DR (2002) Electrodereducing microorganisms that harvest energy from marine sediments. Science 295:483-485. https://doi.org/10.1126/science. 1066771

Carlucci AF, Scarpino PV, Pramer D (1961) Evaluation of factors affecting survival of Escherichia coli in sea water. V. Studies with heatand filter-sterilized sea water. Appl Microbiol 9:400-404

D'Costa VM, McGrann KM, Hughes DW, Wright GD (2006) Sampling the antibiotic resistome. Science 311:374-377. https://doi.org/10. 1126/science. 1120800

Enzinger RM, Cooper RC (1976) Role of bacteria and protozoa in the removal of Escherichia coli from estuarine waters. Appl Environ Microbiol 31:758-763
Feng F, Goto D, Yan T (2010) Effects of autochthonous microbial community on the die-off of fecal indicators in tropical beach sand. FEMS Microbiol Ecol 74:214-225. https://doi.org/10.1111/j.15746941.2010.00921.x

Fredrickson JK et al (2008) Towards environmental systems biology of Shewanella. Nat Rev Microbiol 6:592-603. https://doi.org/10.1038/ nrmicro1947

Gödeke J, Heun M, Bubendorfer S, Paul K, Thormann KM (2011) Roles of two Shewanella oneidensis MR-1 extracellular endonucleases. Appl Environ Microbiol 77:5342-5351. https://doi.org/10.1128/ aem.00643-11

Gonzalez JM, Iriberri J, Egea L, Barcina I (1992) Characterization of culturability, protistan grazing, and death of enteric bacteria in aquatic ecosystems. Appl Environ Microbiol 58:998-1004

Gonzalez-Flecha B, Demple B (1995) Metabolic sources of hydrogen peroxide in aerobically growing Escherichia coli. J Biol Chem 270:13681-13687

Hibbing ME, Fuqua C, Parsek MR, Peterson SB (2010) Bacterial competition: surviving and thriving in the microbial jungle. Nat Rev Microbiol 8:15-25. https://doi.org/10.1038/nrmicro2259

Imlay JA (2013) The molecular mechanisms and physiological consequences of oxidative stress: lessons from a model bacterium. Nat Rev Microbiol 11:443-454. https://doi.org/10.1038/nrmicro3032

Jahn MK, Haderlein SB, Meckenstock RU (2005) Anaerobic degradation of benzene, toluene, ethylbenzene, and o-xylene in sediment-free iron-reducing enrichment cultures. Appl Environ Microbiol 71: 3355-3358. https://doi.org/10.1128/aem.71.6.3355-3358.2005

Jannasch HW (1968) Competitive elimination of Enterobacteriaceae from seawater. Appl Microbiol 16:1616-1618

Kapetas L, Ngwenya BT, MacDonald AM, Elphick SC (2012) Thermodynamic and kinetic controls on cotransport of Pantoea agglomerans cells and zn through clean and iron oxide coated sand Columns. Environ Sci Technol 46:13193-13201. https://doi.org/10. 1021/es302801a

Kazumi J, Haggblom MM, Young LY (1995) Degradation of monochlorinated and nonchlorinated aromatic compounds under iron-reducing conditions. Appl Environ Microbiol 61:4069-4073

Kim JY, Park HJ, Lee C, Nelson KL, Sedlak DL, Yoon J (2010) Inactivation of Escherichia coli by nanoparticulate zerovalent iron and ferrous ion. Appl Environ Microbiol 76:7668-7670. https://doi. org/10.1128/AEM.01009-10

Lee C, Kim JY, Lee WI, Nelson KL, Yoon J, Sedlak DL (2008) Bactericidal effect of zero-valent iron nanoparticles on Escherichia coli. Environ Sci Technol 42:4927-4933

Lonergan DJ, Jenter HL, Coates JD, Phillips EJ, Schmidt TM, Lovley DR (1996) Phylogenetic analysis of dissimilatory Fe(III)-reducing bacteria. J Bacteriol 178:2402-2408

Lovley DR (1991) Dissimilatory Fe(III) and Mn(IV) reduction. Microbiol Rev 55:259-287

Lovley DR (2006) Microbial Fe(III) reduction in subsurface environments. FEMS Microbiol Rev 20:305-313

Lovley DR, Lonergan DJ (1990) Anaerobic oxidation of toluene, phenol, and $\mathrm{p}$-cresol by the dissimilatory iron-reducing organism, GS-15. Appl Environ Microbiol 56:1858-1864

Lovley DR, Phillips EJP (1986) Organic matter mineralization with reduction of ferric iron in anaerobic sediments. Appl Environ Microbiol 51:683-689

Lovley DR, Phillips EJP (1988) Novel mode of microbial energy metabolism: organic carbon oxidation coupled to dissimilatory reduction of iron or manganese. Appl Environ Microbiol 54:1472-1480

Lovley DR, Baedecker MJ, Lonergan DJ, Cozzarelli IM, Phillips EJP, Siegel DI (1989) Oxidation of aromatic contaminants coupled to microbial iron reduction. Nature 339:297-300

Lovley DR, Phillips EJP, Lonergan DJ (1991) Enzymic versus nonenzymic mechanisms for iron(III) reduction in aquatic sediments. Environ Sci Technol 25:1062-1067 
Lovley DR, Phillips EJ, Caccavo F Jr (1992) Acetate oxidation by dissimilatory Fe(III) reducers. Appl Environ Microbiol 58:3205-3208

Lovley DR, Coates JD, BluntHarris EL, Phillips EJP, Woodward JC (1996) Humic substances as electron acceptors for microbial respiration. Nature 382:445-448. https://doi.org/10.1038/382445a0

Lu W, Wang H, Huang C, Reichardt W (2008) Aromatic compound degradation by iron reducing bacteria isolated from irrigated tropical paddy soils. J Environ Sci 20:1487-1493. https://doi.org/10.1016/ S1001-0742(08)62554-1

Marozava S, Roling WF, Seifert J, Kuffner R, von Bergen M, Meckenstock RU (2014) Physiology of geobacter metallireducens under excess and limitation of electron donors. Part II. Mimicking environmental conditions during cultivation in retentostats. Syst Appl Microbiol 37:287-295. https://doi.org/10.1016/j.syapm.2014. 02.005

Medema GJ, Bahar M, Schets FM (1997) Survival of Cryptosporidium parvum, Escherichia coli, fecal Enterococci and Clostridium perfringens in river water: influence of temperature and autochthonous microorganisms. Water Sci Technol 35:249-252

Mills AL, Herman JS, Hornberger GM, DeJesús TH (1994) Effect of solution ionic strength and iron coatings on mineral grains on the sorption of bacterial cells to quartz sand. Appl Environ Microbiol 60:3300-3306

Mitchell R, Nevo Z (1965) Decomposition of structural polysaccharides of bacteria by marine microorganisms. Nature 205:1007-1008

Mitchell R, Yankofsky S, Jannasch HW (1967) Lysis of Escherichia coli by marine microorganisms. Nature 215:891-893

Newman DK, Kolter R (2000) A role for excreted quinones in extracellular electron transfer. Nature 405:94-97. https://doi.org/10.1038/ 35011098
Obuekwe CO, Westlake DW, Cook FD (1981) Effect of nitrate on reduction of ferric iron by a bacterium isolated from crude oil. Can J Microbiol 27:692-697

Reguera G, McCarthy KD, Mehta T, Nicoll JS, Tuominen MT, Lovley DR (2005) Extracellular electron transfer via microbial nanowires. Nature 435:1098-1101. https://doi.org/10.1038/nature03661

Rozen Y, Belkin S (2001) Survival of enteric bacteria in seawater. FEMS Microbiol Rev 25:513-529

Seaver LC, Imlay JA (2001) Hydrogen peroxide fluxes and compartmentalization inside growing Escherichia coli. J Bacteriol 183:71827189. https://doi.org/10.1128/JB.183.24.7182-7189.2001

Stookey LL (1970) Ferrozine - a new spectrophotometric reagent for iron. Anal Chem 42:779-781. https://doi.org/10.1021/ac60289a016

USEPA (2002) Method 1603: Escherichia coli (E. coli) in water by membranefiltration using modified membrane-thermotolerant Escherichia coli agar (Modified mTEC), EPA 821-R-02-023. Office of Water, Washington DC

Weber KA, Achenbach LA, Coates JD (2006) Microorganisms pumping iron: anaerobic microbial iron oxidation and reduction. Nat Rev Microbiol 4:752-764. https://doi.org/10.1038/nrmicro1490

Zhang Q, He X, Yan T (2015) Differential decay of wastewater bacteria and change of microbial communities in beach sand and seawater microcosms. Environ Sci Technol 49:8531-8540. https://doi.org/ 10.1021/acs.est.5b01879

Publisher's note Springer Nature remains neutral with regard to jurisdictional claims in published maps and institutional affiliations. 